\title{
THE SPATIAL COMPOSITION OF ALUN-ALUN ON JAVA ISLAND TODAY
}

\author{
Takako Kohori $^{1}$, Akhmad Arifin Hadi², Katsunori Furuya ${ }^{3}$
}

Received: September 16, 2018

Accepted: October 17, 2018

\begin{abstract}
This study focuses on alun-alun, the open spaces in Indonesia that have a long cultural history. Alun-alun mostly located in the center of cities; they influence the pattern of cities and become a mental map for inhabitants. In this study, we investigated the distribution of alun-alun throughout Java Island. The research consisted of three parts. First, we identified Alun-alun from the colonial era using the old maps from Leiden University There were 15 locations of alun-alun in 13 cities identified from the old maps with characteristics as follows; 1) rectangular land, 2) located adjacent to the city mosque, and 3) located adjacent to the Regent's office or Palace. In the second part, from those definitions, we confirmed 90 locations of alun-alun in 87 cities that have existed from the colonial period to the present across Java Island. The third part, we clarified the current province of alun-alun from two perspectives: area and spatial composition. We found that the present alun-alun show regional tendencies. Alun-alun in cities of Banten and West Java province was mostly in a small-scale area without Ficus benjamina trees. These points overlap with features described in the colonial era. Alun-alun in cities of Central Java and Yogyakarta province was relatively in a large-scale area and characterized by Ficus benjamina as the main tree. Alun-alun in cities of East Java province was also in a large-scale area, but space mostly divided by planted areas, open area, structures, and others.
\end{abstract}

Keywords: spatial change, social change, social interaction and adaptation, urban community

\section{INTRODUCTION}

In recent years, owing to rapid changes in the shift from a local to a globalized environment, cities are facing a crisis of how to standardize identities, which in turn forces them to develop strategies to support, sell, and advertise themselves as attractive tourist destinations(Kotler \& Gertner, 2002). Urban culture conservation will be the guide to survival strategies for cities in the $21^{\text {st }}$ century. It is necessary to conserve the city's historic environment to respect the culture of the city. In developing such a plan, we must learn to use new strategies to preserve the structure of the city and its historical heritage(Cohen, 1999). Graham notes that the heritage is a part of the past that we have chosen for economic or cultural purposes in the present(Graham, 2002).

This study focuses on Indonesia, where cities are facing a crisis of change due to rapid expansion and development, where heritages of the city are on the verge of being lost. The official definition of "heritage" used by international organizations has spread(Ahmad, 2006). Previously, it primarily restricted to the tangible heritage of the human archaeological, historical, and cultural past. However, in recent years its definition has been expanded to

\footnotetext{
${ }^{1}$ School of Horticulture, Chiba University, Japan

${ }^{2}$ Department of Landscape Architecture, Faculty of Agriculture, Bogor Agricultural University

${ }^{3}$ School of Horticulture, Chiba University, Japan
} 
include valuable natural sites and intangible cultural treasures. Under such circumstances, we all are asked how to preserve this heritage and utilize it in the future.

In Indonesia, colonial buildings become subject to conservation as a symbol of the region. Conserving building heritage is necessary for the physical and symbolic identity, and it is indispensable to the affluent cities(Lukito \& Rizky, 2017). However, we should point out that the object of conservation in Indonesia is too concentrated in the building. As an official definition by international organizations, open space become recognized as a heritage from the 1975 Amsterdam Declaration(Ahmad, 2006), therefore we try to recognize the historical value of open space in this study. In this study, we focus on green open space "alun-alun" which exists in most cities in Indonesia. Alun-alun is a specific example cities culture. However, the conservation argument in Indonesia does not include much of alun-alun. Perhaps the reason is that alun-alun displays an absence of prominent physical constructs.

The historical elements of cities in Java Island are alun-alun, the regent's office, mosques, and commercial facilities. These four elements are called catur tunggal (four in one) where located at the center of the city. Moreover, there is a prototype for the layout. The regent's office, mosques, and commercial facilities located surround the alun-alun (ikaputra \& Narumi, 1994) thus alun-alun is an important essence in the city.

Regarding the current use, citizen used alun-alun 24 hours a day for any activities such as markets, and special activities such as ceremonies and events. Alun-alun become a part of city that familiar to citizen and become a symbol of the city.

Regarding to the spatial composition of alun-alun, there are two types of alun-alun: first, alun-alun with Ficus Benjamina tree planted in the center of the site, and second, the open space type that spread to the vacant space in the center of the site(Rully Damayanti \& Handinoto, 2005).

Next, the historical background of alun-alun from previous research was identified. Alun-alun existed as part of the palace complex from the Majapahit to the Mataram era (the 13th-18th century). The general population started to used alun-alun during the new Mataram dynasty. Two Ficus Benjamina trees planted in the center of the alun-alun, and 64 Ficus Benjamina planted surrounding. Ficus Benjamina tree was a symbolic tree that expressed unity and harmony between humans and universe, and it was a sacred symbol related to the royal family (Handinoto, 1992).

Later, while the Netherlands dominated the 19th century, they created a new city in Indonesia. Along with development of the cities, the alun-alun were etablished as the center of the city. The existence of alun-alun had incorporated with urban planning in Indonesia cities (Heryanto, 2000), where important cities' buildings and infrastructures were located surround the alun-alun. Alun-alun then took important meaning to connect local people with colonial administrative organizations (Wiryomartono,1995).

Moreover, in 19th century Europe, there was a movement to create open space due to the improvement of sanitary aspects of the city. Through the colonial governance, these concepts applied to Indonesia (Handinoto, 1992). From these social backgrounds, the number of alun-alun had increased. "Encyclopedie van Nederlandsch Indie (1917)" described alun-alun as follows; People could find alun-alun in almost every resident of the Regent, and it was a large lawn and surrounded by Ficus Benjamina tree. Alun-alun in the ancient kingdoms such as Surakarta and Yogyakarta had two alun-alun located in the north of the Palace and south of the Palace. The characteristics of alun-alun's ground is plain without grass covered with fine sand. In West Java, there was also small alun-alun in front of the village head's house without Ficus Benjamina tree. The City's Mosques is an important elements that often located on the west side of alun-alun.

However, in recent years, alun-alun is facing changes caused by cities' development in surrounding spaces of alun-alun. The Indonesian government had the movement to under the initiative to alter alun-alun (Arifin,2013). It began to pay attention to the necessity to plan 
and design the symbolic and aesthetic viewpoint from the user's perspective (Winansih, 2010). There was a positive opinion on alun-alun reconstructions in the young generation, because of the improvement of facilities and usage as entertainment (Kohori \& Furuya, 2015). Moreover, young people did not recognize alun-alun 's history and culture enough (Kohori \& Furuya, 2017). Urban sprawl also affected the existence of alun-alun. Many cities' center shifted and changed old alun-alun to another type of square at the new city center (Rukayah, 2012).

From the previous research, it identified that alun-alun established according to various historical backgrounds and become an asset in the historical heritage representing culture and history of Indonesia. However, people still not respect the history of alun-alun enough, especially to Alun-alun which existed for about 100 years since the colonial era.

From the discussion above, it is apparent that the preservation of alun-alun authenticity is facing a crisis that the term of "alun-alun" has used freely. Any space that has a rectangular shape is possible to be called as alun-alun although it is newly established. However, the actual conditions of those places are quite different from the historical characteristics of the original alun-alun. Thus, the various perceptions alun-alun term is likely to lead to the fact that people are not fully aware of their historical value.

This study poses several questions to a study of alun-alun identity: How are alun-alun distributed from the colonial period to the present? What are the characteristics of alun-alun? Is there a regional trend in the features of alun-alun? How can we use alun-alun while preserving alun-alun as Javanese culture's heritage? In order to provide preliminary answers to these queries, we collected the map data of Java Island from the colonial era to the present and use it to clarify the features of current alun-alun from the viewpoint of space composition. Our results provide the first step for people to understand the historical value of alun-alun and recognize them as regional assets.

\section{METHOD}

From the 19th to the 20th century, Indonesia was a country that changed rapidly from the period of Dutch colonial era, the Japanese colonial era to the independence era. During that era, historical documents about alun-alun are insufficient. In this research, we mainly used map data to investigate alun-alun. We studied following maps: 1) maps from the Dutch colonial era owned by Leiden University, 2) maps from the Japan colonial era owned by Leiden University, 3) maps published by Bakosurtanal (now it changed to Badan Informasi dan Geospatial or BIG), Indonesia on 1995, and 4) current Aerial Photos and data published by Google Earth Pro. To comprehensively grasp the locations of alun-alun in the colonial era, we used Maps 1) and 2). In Maps 1) and 2), we focused on a topographic map of 1:25,000 and city maps of Java Island, where alun-alun could identify by land use. However, in some areas of the provinces of Central Java and East Java, we only could obtain the map of 1 : 50,000. In Map 3), we obtained 151 maps of the entire island from Bakosurtanal.

This study consisted of the following three parts. First, we extracted the places described on the map of alun-alun in the colonial era that the name of buildings and infrastructures were written clearly on the map. All the name of buildings and infrastructures surrounding alun-alun were identified to define the spatial form of alun-alun. The maps' information that used in this survey was written on Table 1. Using those definitions, we extracted alun-alun that had existed from the colonial period to the present across the whole island. Finally, the current appearance of the extracted alun-alun summarized from two perspectives: 1) area and 2) spatial composition. We focused on the spatial trends of surrounding spaces of alun-alun. The aerial photographs images from Google Earth Pro and measurements tool of this software were supplementary material in this research. 
Table 1: The source of alun-alun maps in the Dutch colonial era

\begin{tabular}{llllll}
\hline No. & City name & Year & Scale & Map type & Document number \\
\hline 1. & Bandung & 1921 & $1: 5000$ & city maps & $03848-4$ \\
2. & Cirebon & 1921 & $1: 5000$ & city maps & 03933 \\
3. & Tegal & 1918 & $1: 25000$ & topographic maps & $05075-116$ \\
4. & Banyumas & 1920 & $1: 2500$ & city maps & 03925 \\
5. & Magelang & 1923 & $1: 2500$ & city maps & $03946-1$ \\
6. & Serakarta & 1927 & $1: 25000$ & topographic maps & $05075-460$ \\
7. & Yogyakarta & 1925 & $1: 10000$ & city maps & 03868 \\
8. & Wonosari & 1932 & $1: 25000$ & topographic maps & $05075-404$ \\
9. & Madiun & 1917 & $1: 5000$ & city maps & $03943-1$ \\
10. & Kediri & 1913 & $1: 5000$ & city maps & 03942 \\
11. & Bangkalan & 1919 & $1: 20000$ & topographic maps & $05053-003$ \\
12. & Malang & 1946 & $1: 10000$ & city maps & 03947 \\
13. & Banyuwangi & 1916 & $1: 5000$ & city maps & 03929 \\
\hline
\end{tabular}

Source: Leiden University

\section{RESULT AND DISCUSSION}

\section{Characteristics of alun-alun from the Dutch colonial era maps}

In the old maps of Dutch colonial era published by Leiden University, we confirmed the space specified as alun-alun in a total of four provinces and 13 cities, including Bandung, Cirebon, Tegal, Banyumas, Magelang, Surakarta, Yogyakarta, Wonosari, Madiun, Kediri, Malang, Banyuwangi, and Bangkalan city. The relationship between alun-alun and the surrounding facilities drew in Figure 1. according to spatial land use surround alun-alun, there are two major characteristics of alun-alun, including near the palace and the regent's office.In Surakarta and Yogyakarta city, alun-alun located near the Javanese Kingdom palace. In those cities, alun-alun existed on the same zone to the palace while the other alunalun did not locate near palace but more to adjacent to regent's office.

In Surakarta and Yogyakarta city, alun-alun located near Javanese kingdom palace. The alun-alun shape was a rectangle. There are two alun-alun, North alun-alun and South alun alun. The palace located between the two alun-alun. In both Surakarta and Yogyakarta city, the north side of alun-alun was described in the map with connecting buildings as part of the palace. The other similarity is the location of city mosque located on the west side of the north alun-alun.

In Bandung, Cirebon, Tegal, Tegal, Banyumas, Magelang, Wonosari, Madiun, Kediri, Malang, Banyuwangi, and Bangkalan city (next we called it as 11 cities), the alun-alun were adjacent to the regent's office. The alun-alun shape was a rectangle. We identified the buildings' name and the land-use surround alun-alun. It found that the city mosque was adjacent to alun-alun of 10 cities. Beside mosque, the schools including "vocational training schools" and "European's school" were adjacent to alun-alun of 11 cities. Prisons that become an important building in a colonial-era established in 5 cities. The other buildings and infrastructures such as the post office, telegram station, telephone office, and so on were located surround alun-alun of 11 cities.

According to these results, we defined the spatial form of alun-alun in this study from the existence of the regent's office or palace, the presence of the mosque, and the presence of the school. The previous studies have also described the relationship between alun-alun and various facilities, however our study was confirming the actual relationship between alun-alun and the various facilities based on the land use today and the past. 


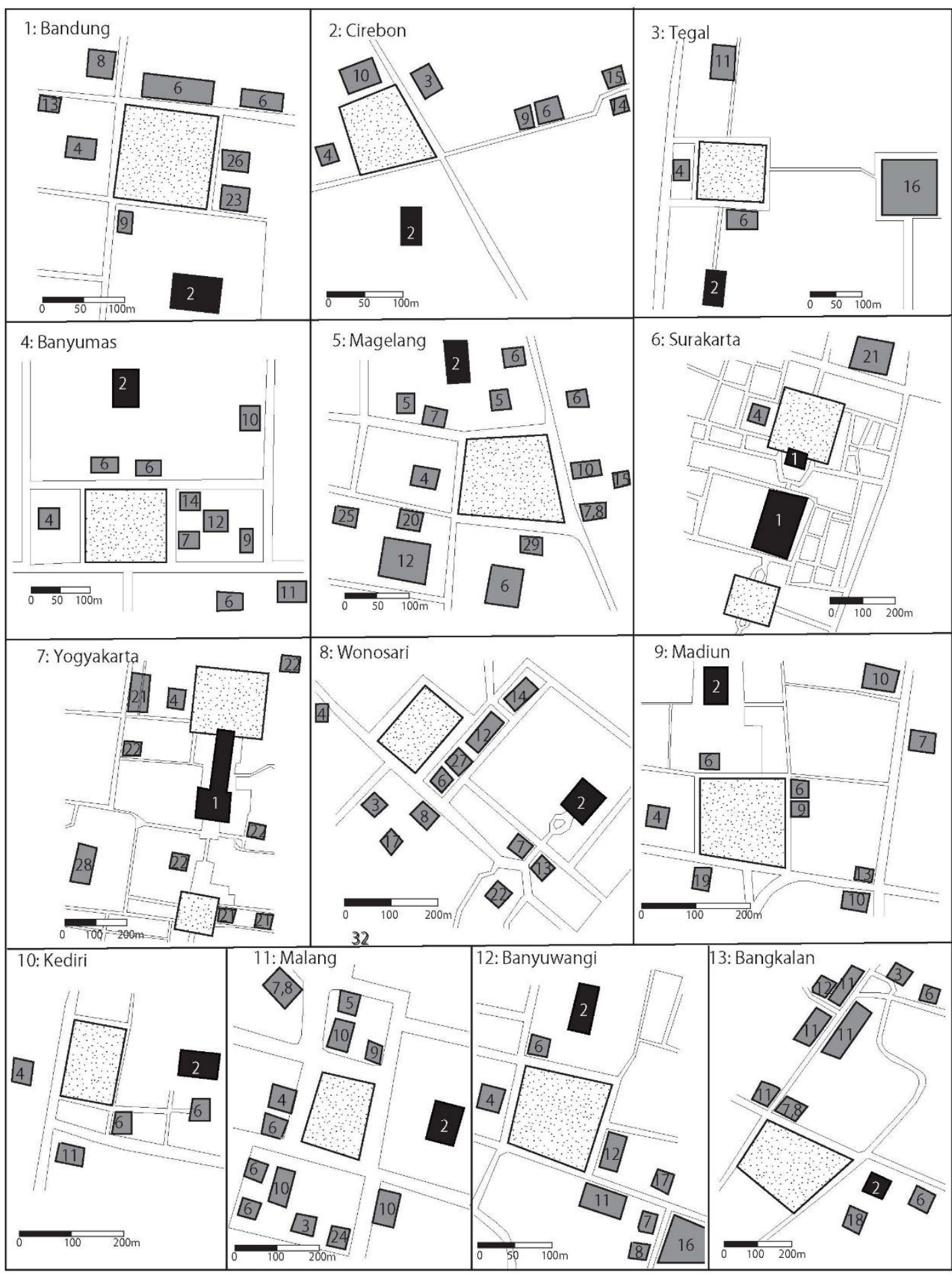

[legend]1.Palace, 2. Regent office, 3. Assistant Regent office, 4. Mosque, 5. Church, 6. School, 7. Telecommunication or Telephone office, 8. Post office, 9. Bank, 10. Hotel,

11. Market, 12. Prison, 13. Drugstore, 14. Hospital, 15. Factory, 16.Park, 17. Christian Cemetery, 18. Barrack army, 19.Chinese captain house, 20.Fire station, 21.Fortress,

22. Government staff settlements, 21. Kingdom Staff Settlements, 22. Kingdom Family Settlements, 23. Movie Theater, 24.Pawn shop, 25. Police, 26. Restaurant, 27. Resident settlement, 28Water castle, 29:Water management office,

Source: Digitized from maps of Leiden University

Figure 1: Maps of 13 Cities From The Dutch Colonial Era. 
Table 2: Spatial features on Alun-alun perimeters by city

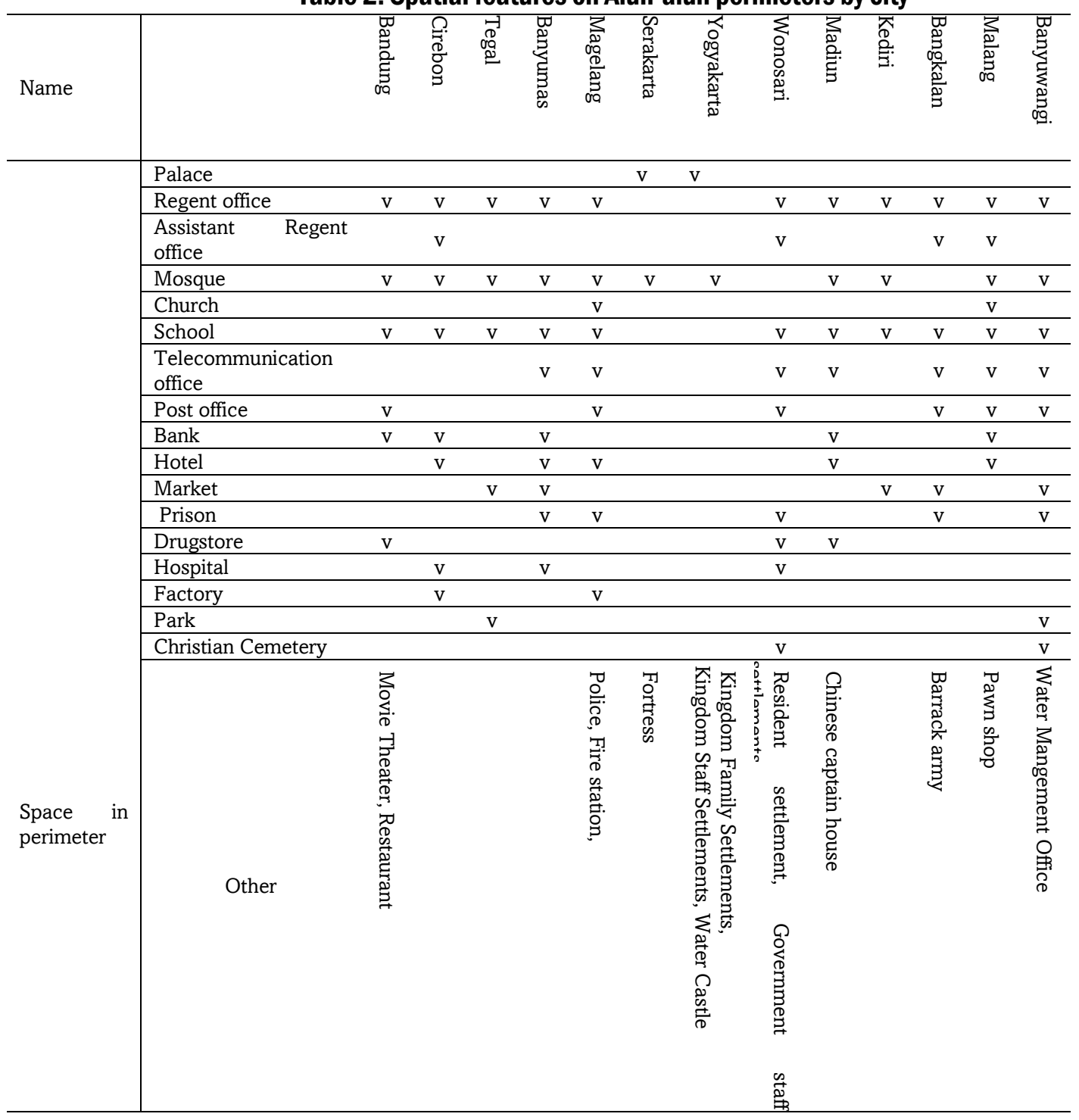

Souce: Digitized from Leiden University maps

\section{Distribution of Alun-Alun Over All of Java}

Based on the above results, the position of alun-alun was extracted based on the following three points in this study: 1) rectangular land, 2) located adjacent to the mosque, and 3) located adjacent to regent's office or palace. In the colonial map, "mosque," "regent's office," and "palace" were described by symbols and names; however, "school" did not describe in this way on the map, we excluded it from the extraction.

From our survey, we revealed that there were 90 alun-alun exist in 87 cities from past to present. The alun-alun were distributed widely over the area of Java Island (figure 2). The present alun-alun were identified in Banten province (3 alun-alun), West Java province (35 alun-alun), Central Java province (19 alun-alun), Special Region of Yogyakarta (4 alun-alun) and East Java (29 alun-alun). We could not confirm any alun-alun location in the Special Capital Region of Jakarta. The alun-alun in West Java province were located in inland cities, 
and especially concentrated around Bandung city (B8) while the alun-alun in Central Java and East Java province were distributed both of inland cities and coastal cities.

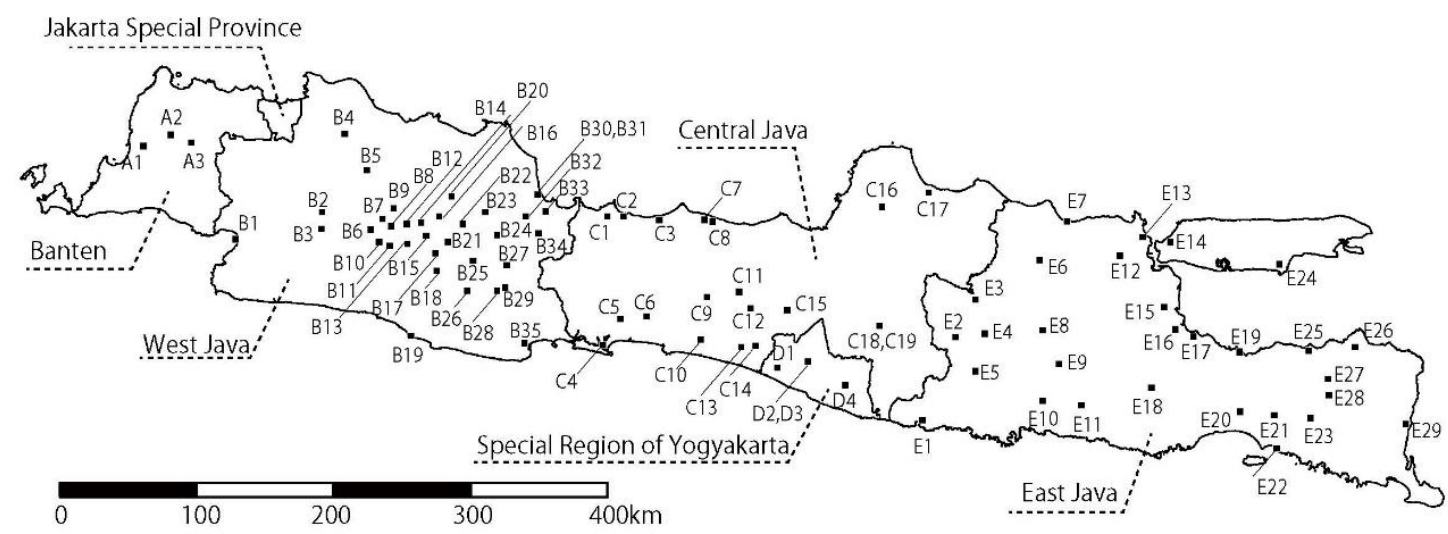

Source: mapped from google earth data

Figure 2: Diagram of the position of Alun-alun on Java Island

\section{The Area of Each Alun-Alun}

The area of each alun-alun in each city we measured and analyzed to identify the characteristics of alun-alun based on city and province (figure 3). Moreover, we calculated the median value, the standard deviation value, the maximum value, and the minimum value of the area of alun-alun of each province in Table 3. From the analysis we identified that 1) In Banten and West Java provinces, the standard deviation was small which is means that the area of Alun-alun of those provinces were similar. In West Java, the the area of alun-alun mostly 1.5 ha or less. 2) In Central Java, the area of alun-alun of each city were various. 3) In East Java, that alun-alun Ngawi city (6.89 ha) was the largest alun-alun in East Java. It was the outlier by the definition of the interquartile range. Mostly the area of alun-alun in East java was 1.0 ha to 4.0 ha. 4) The maximum value of area of alun alun in Central Java province, Special Region of Yogyakarta, and East Java province were similar.

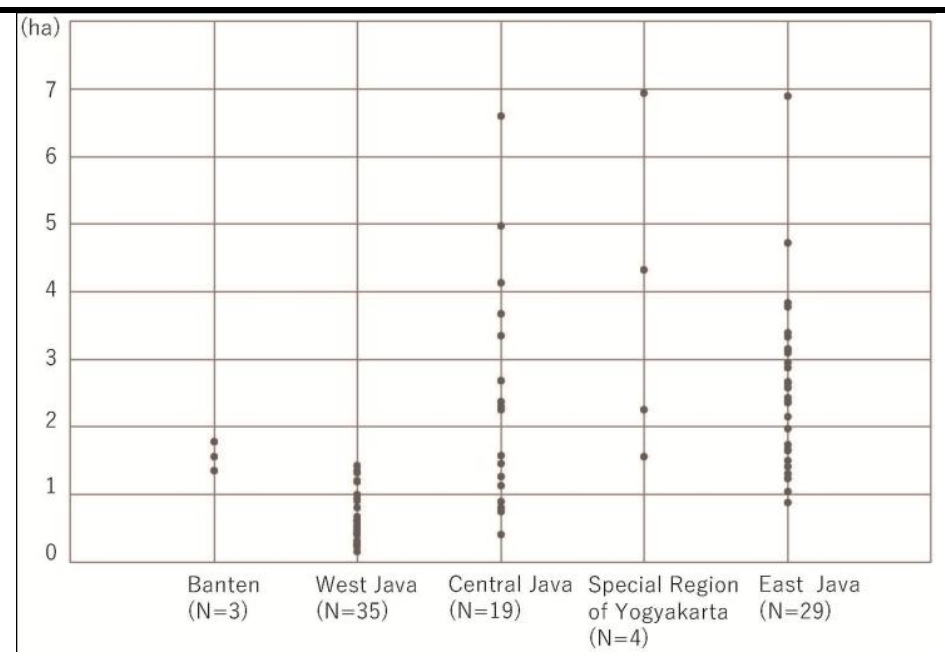

Source: Digitized from Google earth data

Figure 3: Plot diagram of Alun-alun area in ha by state 
Table 3: Area of Alun-alun by province

\begin{tabular}{lrrrrrc}
\hline & \multicolumn{1}{l}{$\begin{array}{l}\text { Banten } \\
(\mathrm{N}=3)\end{array}$} & $\begin{array}{l}\text { West Java } \\
(\mathrm{N}=35)\end{array}$ & $\begin{array}{l}\text { Central Java } \\
(\mathrm{N}=19)\end{array}$ & $\begin{array}{l}\text { Special Region } \\
\text { of Yogyakarta } \\
(\mathrm{N}=4)\end{array}$ & $\begin{array}{l}\text { East } \\
(\mathrm{N}=29)\end{array}$ & Java \\
\hline Median Value & 1.56 & 0.51 & 1.58 & 3.30 & $2.43(2.41)$ \\
Standard Deviation & 0.18 & 0.36 & 1.62 & 2.09 & $1.22(0.92)$ \\
Maximum Value & 1.78 & 1.43 & 6.60 & 6.94 & 6.89 \\
Minimum Value & 1.35 & 0.16 & 0.42 & 1.56 & 0.88 \\
\hline
\end{tabular}

Table 4. Area of Alun-Alun by The Inland City and The Coastal City

\begin{tabular}{|c|c|c|c|c|}
\hline & \multicolumn{2}{|c|}{ Central Java } & \multicolumn{2}{|c|}{ East Java } \\
\hline & $\begin{array}{l}\text { Inland city } \\
\quad(N=12)\end{array}$ & $\begin{array}{l}\text { coastal city } \\
\quad(\mathrm{N}=7)\end{array}$ & $\begin{array}{l}\text { inland city } \\
\quad(\mathrm{N}=17)\end{array}$ & $\begin{array}{c}\text { coastal city } \\
(\mathrm{N}=12)\end{array}$ \\
\hline Median Value & 2.53 & 1.13 & 2.64 & 2.40 \\
\hline Standard Deviation & 1.69 & 0.37 & 1.46 & 0.68 \\
\hline Maximum Value & 6.60 & 1.58 & 6.89 & 3.33 \\
\hline Minimum Value & 0.74 & 0.42 & 0.88 & 1.23 \\
\hline
\end{tabular}

Source: Digitized from Google earth data

Next, we focused on the data considering the location of the city. The inland city and the coastal city in Central Java and East Java province had different characteristics. In the survey, we regarded the city located within $10 \mathrm{~km}$ from the coast as the coastal city. In Central Java, there were 12 inland cities and seven coastal cities. In East Java, there were 17 inland cities and 12 coastal cities. The plot diagram of area of alun-alun in each city were described in Figure 4 and Figure 5. The median value, the standard deviation value, the maximum value, and the minimum value of area of alun-alun were written in Table 4.

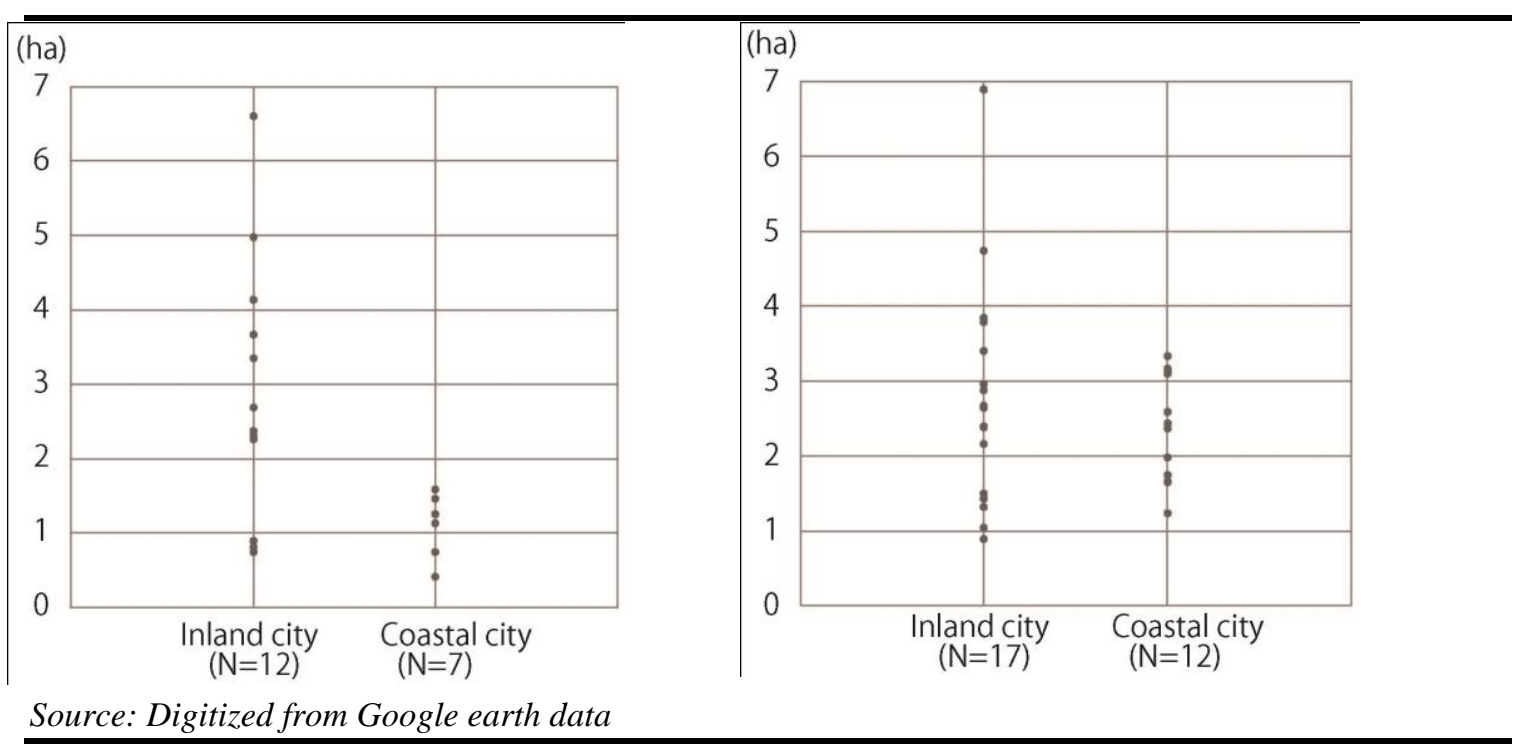

Figure 4: Plot Diagram of Central Java (left) and Plot Diagram of East Java (right) 
Table 5 Detailed Data of Alun-alun

\begin{tabular}{|c|c|c|c|c|}
\hline Province & No. & City Name & Area (ha) & Spatial Composition \\
\hline \multirow{3}{*}{ Banten } & $\mathrm{A} 1$ & Menes & 1.35 & open space \\
\hline & A2 & Pandeglang & 1.78 & open space \\
\hline & A3 & Rangkasbitung & 1.56 & open space \\
\hline \multirow{35}{*}{ West Java } & B1 & Palabuhan & 0.44 & open space \\
\hline & B2 & Cianjur & 0.81 & ornamental structure \\
\hline & B3 & Cibeber & 0.16 & open space \\
\hline & B4 & Krawang & 0.42 & ornamental structure \\
\hline & B5 & Purwakarta & 0.26 & ornamental structure \\
\hline & B6 & Cililin & 0.42 & open space \\
\hline & B7 & Cimahi & 0.42 & open space \\
\hline & B8 & Bandung* & 1.21 & open space \\
\hline & B9 & Lembang & 0.30 & open space \\
\hline & B10 & Soreang & 0.62 & open space \\
\hline & B11 & Banjaran & 0.63 & open space \\
\hline & B12 & UjungBerung & 0.54 & open space \\
\hline & B13 & Ciparay & 0.33 & ornamental structure \\
\hline & B14 & Tanjungsari & 0.42 & open space \\
\hline & B15 & Cicalengka & 0.23 & ornamental structure \\
\hline & B16 & Sumedang & 1.43 & ornamental structure \\
\hline & B17 & Leles & 0.63 & open space \\
\hline & B18 & Garut & 1.19 & open space \\
\hline & B19 & Pameungpeuk & 0.25 & open space \\
\hline & $\mathrm{B} 20$ & Conggeang & 0.27 & open space \\
\hline & B21 & Bluburlimbangan & 0.47 & open space \\
\hline & B22 & Darmaraja & 0.26 & open space \\
\hline & $\mathrm{B} 23$ & Majalengka & 1.33 & open space \\
\hline & B24 & Talaga & 0.63 & open space \\
\hline & B25 & Ciawi & 0.32 & open space \\
\hline & B26 & Singaparna & 0.61 & ornamental structure \\
\hline & B27 & Kawali & 0.91 & ornamental structure \\
\hline & B28 & Manonjaya & 0.95 & open space \\
\hline & B29 & Ciamis & 1.36 & ornamental structure \\
\hline & B30 & Cirebon (Kasepuhan) & 1.00 & open space \\
\hline & B31 & Cirebon (Kejaksaan)* & 1.19 & open space \\
\hline & B32 & Cilimus & 0.28 & ornamental structure \\
\hline & B33 & Lemahabang & 0.51 & open space \\
\hline & B34 & Ciawigebang & 0.42 & open space \\
\hline & B35 & Parigi & 0.68 & open space \\
\hline \multirow[t]{16}{*}{ Central } & $\mathrm{C} 1$ & Brebes & 0.75 & open space \\
\hline & $\mathrm{C} 2$ & Tegal* $^{*}$ & 1.46 & open space \\
\hline & $\mathrm{C} 3$ & Pemalang & 1.26 & 2ficus benjamina+site division \\
\hline & $\mathrm{C} 4$ & Cilacap & 1.13 & open space \\
\hline & $\mathrm{C} 5$ & Jatiwangi & 0.81 & open space \\
\hline & C6 & Banyumas* & 2.26 & open space \\
\hline & $\mathrm{C} 7$ & Pekalongan & 1.13 & open space \\
\hline & $\mathrm{C} 8$ & Batang & 1.58 & 1 ficus benjamina \\
\hline & $\mathrm{C} 9$ & Banjarnegara & 2.37 & 2 ficus benjamina \\
\hline & $\mathrm{C} 10$ & Kebumen & 3.67 & 1 ficus benjamina \\
\hline & $\mathrm{C} 11$ & Wonosobo & 3.35 & 1 ficus benjamina \\
\hline & $\mathrm{C} 12$ & Sapuran & 0.74 & open space \\
\hline & $\mathrm{C} 13$ & Kutoarjo & 2.68 & 1 ficus benjamina \\
\hline & $\mathrm{C} 14$ & Purworejo & 6.6 & 2 ficus benjamina \\
\hline & $\mathrm{C} 15$ & Magelang* & 2.3 & 1 ficus benjamina \\
\hline & $\mathrm{C} 16$ & Kudus & 0.89 & open space \\
\hline
\end{tabular}




\begin{tabular}{|c|c|c|c|c|}
\hline Province & No. & City Name & Area (ha) & Spatial Composition \\
\hline & $\mathrm{C} 17$ & Juwana & 0.42 & open space \\
\hline & $\mathrm{C} 18$ & Serakarta (north)* & 4.13 & 2 ficus benjamina \\
\hline & $\mathrm{C} 19$ & Serakarta (south)* & 4.97 & 2 ficus benjamina \\
\hline \multirow[t]{4}{*}{ Special } & D1 & Wates & 4.33 & 2 ficus benjamina \\
\hline & D2 & Yogyakarta(north)* & 6.94 & 2 ficus benjamina \\
\hline & D3 & Yogyakarta(south)* & 2.26 & 2 ficus benjamina \\
\hline & D4 & Wonosari* & 1.56 & 2 ficus benjamina \\
\hline \multirow[t]{29}{*}{ East Java } & E1 & Pacitan & 2.58 & site division \\
\hline & E2 & Magetan & 2.16 & 1ficus benjamina+site division \\
\hline & E3 & Ngawi & 6.89 & ornamental structure \\
\hline & E4 & Madiun* & 2.87 & site division \\
\hline & E5 & Ponorogo & 3.40 & 2 ficus benjamina \\
\hline & E6 & Bojonegoro & 2.37 & ornamental structure \\
\hline & E7 & Tuban & 3.14 & 2 ficus benjamina \\
\hline & E8 & Nganjuk & 1.50 & 1 ficus benjamina + ornamental structure \\
\hline & E9 & Kediri* & 0.88 & ornamental structure \\
\hline & E10 & Tulungagung & 1.42 & ornamental structure \\
\hline & E11 & Blitar & 2.95 & 1 ficus benjamina \\
\hline & E12 & Lamongan & 2.39 & ornamental structure \\
\hline & E13 & Sidaju & 3.33 & ornamental structure \\
\hline & E14 & Bangkalan* & 2.43 & ornamental structure \\
\hline & E15 & Sidoarjo & 3.78 & ornamental structure \\
\hline & E16 & Bangil & 1.97 & 1 ficus benjamina+site division \\
\hline & E17 & Pasuruan & 1.74 & ornamental structure \\
\hline & E18 & Malang* & 2.64 & ornamental structure \\
\hline & E19 & Probolinggo & 3.16 & site division \\
\hline & E20 & Lumajang & 3.84 & 1 ficus benjamina + ornamental structure \\
\hline & E21 & Tanggul & 1.31 & open space \\
\hline & E22 & Puger & 1.23 & open space \\
\hline & E23 & Jember & 2.67 & open space \\
\hline & E24 & Pamekasan & 3.10 & ornamental structure \\
\hline & E25 & Besuki & 1.66 & open space \\
\hline & E26 & Situbondo & 2.36 & site division \\
\hline & E27 & Bondowoso & 4.73 & 1ficus benjamina+site division \\
\hline & E28 & Tamanan & 1.04 & open space \\
\hline & E29 & Banyuwangi* & 1.65 & ornamental structure \\
\hline
\end{tabular}

Source: Digitized from Google earth data

\section{Spatial Composition Within Alun-Alun Site}

We divided the spatial composition inside the alun-alun. We focused on historical and modern characteristics. Historical characteristics included the presence of open space and the number of Ficus Benjamina tree. Modern characteristics included the presence of ornamental structures and the site division. As a result, we divided the sites into the following six types: 1) open space, 2) one Ficus benjamina tree, 3) two Ficus benjamina trees, 4) ornamental structure, 5) divided by elements, and 6) other. Some alun-alun had both historical and modern features together, in which case, we listed both in the table. The following four points read from this: 1) in West Java, there was no alun-alun that involved the presence of Ficus benjamina trees, 2) in Central Java, all alun-alun involved the presence of open space or Ficus benjamina trees, 3 ) in the Special Region of Yogyakarta, all alun-alun had two Ficus benjamina trees, and 4) some of the cities in East Java, alun-alun divided in half and used separately as a planting zone, an open-space zone, or for other purposes. 


\section{CONCLUSION}

In the present, various open spaces are calling as alun-alun. Under such circumstances, we tried to indicat the alun-alun which existed from the colonial era onwards. In this study, we investigated alun-alun from a spatial morphological viewpoint. Based on the definition of alun-alun, we consistently extracted alun-alun's spaces and characterized them using colonial era maps, 1995 maps published by the Indonesian government, and aerial photos and data published by Google Earth Pro in 2017.

In the cities of Banten and West Java provinces, the area of alun-alun had small sizes. In West Java province, the value of the area was close and concentrated to 1.5 ha or less. Moreover, most of the spatial composition was the open-space, and there was no Ficus Benjamina tree planted in the center.

In the cities of Central Java province, the area of alun-alun had various sizes, the area size of the inland cities and the coastal cities was a different characteristic. In the coastal cities, the value of the area was close and concentrated to about 0.5 ha to 1.5 ha. Moreover, all of the spatial composition inside the alun-alun had historical characteristics like the presence of open space or Ficus benjamina tree. In the cities of Special Region of Yogyakarta, the area of alun-alun had various sizes, all of the spatial composition inside the alun-alun had two Ficus benjamina tree. In the cities of East Java, the area of alun-alun concentrated between 1.0 ha and 4.0 ha without the outliner. The area size of the inland cities and the coastal cities was a different characteristic, and the coastal cities were smaller and less difference in the area size. There was a unique composition in alun-alun in these cities and divided into open spaces, planted spaces, structures, and facilities. From the results, it became clear that alun-alun had regional tendencies; the difference by the provinces, and the difference of the inland and the coastal.

In this way, the historical background has persisted to the present, and it became clear that it remains as a regionally unique feature. It is useful for considering the historical position of Alun-alun in urban and spatial planning in Indonesia.

\section{REFERENCES}

Ahmad, Y. (2006). The Scope and Definitions of Heritage : From Tangible to Intangible. International Journal of Heritage Studies, 12(April 2013), 37-41.

Cohen, N. (1999). Urban Conservation. In The MIT Press, Cambridge.

Graham, B. (2002). Heritage as Knowledge: Capital or Culture? Urban Studies, 39, 5-6.

Hadi Susilo Arifin (2013). Alun-alun dan Taman Kota. Radar Cirebon Group, Rabu Wage10 April 2013

Handinoto. (1992). ALUN-ALUN SEBAGAI IDENTITAS KOTA JAWA, DULU DAN SEKARANG. Dimensi Teknik Arsitektur, 18(1), 1-15.

Heryanto, B. (2000). Urban Form of Indonesia Cities During the Colonization Period. Sci\&tech, 2(1), p.11-20.

Ikaputra, \& Narumi, K. (1994). A study on the Transformation of Symbolic Square in Javanese Historical Cities. Papers of the annual conference of the City Planning Institute of Japan, 29, 337-342

Kohori, T., \& Furuya, K. (2015). Study on the influences to student's recognition and activity by the change of alun-alun. Japanese Institute of Landscape Architecture, 8(5), 573-578.

Kohori, T., \& Furuya, K. (2017). The characteristics of Indonesian open space image based on the space configuration. Japanese Institute of Landscape Architecture, 80(5), 579-584.

Kotler, P., \& Gertner, D. (2002). Country as brand, product, and beyond: A place marketing and brand management ...

Lukito, Y. N., \& Rizky, A. N. (2017). Enganging the past of the city through the conservation of heritage building Enganging the past of the city through the conservation of heritage building. Earth and Environmental Science, 99, 0-8.

Rukayah, R. S. (2012). Bazaar in Urban Open Space as Contain and Container Case study: Alun-alun Lama and Simpang Lima Semarang, Central Java, Indonesia. Procedia - Social and Behavioral Sciences, 50, 741755. 
Rully Damayanti, \& Handinoto. (2005). Kawasan "pusat kota" dalam perkembangan sejarah perkotaan di jawa. Dimensi Teknik Arsitektur, 33(1), 34-42.

Winansih, E. (2010). Estetika simbolis - sensori pada ruang publik di alun- alun malang, (September), 20-28.

Wiryomartono. (1995). Seni Bangunan dan Seni Bina Kota di Indonesia: Kajian mengenai Konsep, Struktur dan Elemen Fisik Kota Sejak Peradaban Hindu, Buddha, Islam Hingga Sekarang. Jakarta: Penerbit PT Gramedia Pustaka 